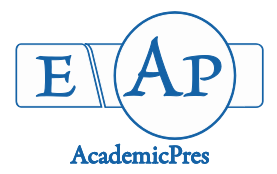

\title{
Genetic Control and Heterosis of Quantitative Traits in Several Local Eggplant Genotypes
}

\author{
Ndueso M. AKPAN*, Peter E. OGBONNA, Vincent N. ONYIA, \\ Emeka C. OKECHUKWU, Ima-obong I. DOMINIC, Agatha I. ATUGWU \\ University of Nigeria, Nsukka, Faculty of Agriculture, Department of Crop Science, Enugu State, Nigeria; \\ akpandueso@yahoo.com (*correspondingauthor),ogbonnaptr@yahoo.com; vincent.onyia@unn.edu; ng,emeka.okechukwu@unn.edu.ng; \\ dominicimaobong@gmail.com; agatha.atugwu@unn.edu.ng
}

\begin{abstract}
The present study was performed to assess the nature of gene action governing inheritance of agronomic traits in eggplant genotypes and extent of mid parent heterosis $(\mathrm{MPH})$ and better parent heterosis $(\mathrm{BPH})$ in six eggplant hybrids generated from four superior and optimally divergent genotypes of eggplant namely 'Yalo', 'Uyo', 'K3' and 'Iyoyo' selected from the germplasm and were crossed in $4 \times 4$ half diallel mating design. The six hybrids were found to show a significant $(\mathrm{p}<0.05)$ positive MPH in yield traits and the highest was obtained in the hybrid 'Yalo' $\times$ 'K3' for number of fruits per plant (158.90\%) and 'K3' × 'Iyoyo' for fruit yield per plant (63.14\%) and fruit yield per hectare (62.20\%). The hybrid combinations 'Yalo' $\times$ 'K3' and 'K3' $\times$ 'Iyoyo' had significant positive BPH for the number of fruits per plant, $104.08 \%$ and $42.43 \%$, respectively. For fruit yield per plant, the hybrid combination 'Yalo' × 'K3' (7.93\%), 'Uyo' × 'K3' (8.48\%) and 'K3' × 'Iyoyo' (12.26\%) had significant positive $\mathrm{BPH}$. However, the hybrid 'K3' × 'Iyoyo' (11.51\%) showed significant positive BPH in fruit yield per hectare. Dominance and dominance $\times$ dominance gene effect were found to be positively higher in magnitude in all crosses for number of fruits per plant, fruit yield per plant and fruit yield per hectare. The prevalence of dominance and dominance $x$ dominance gene effect in the yield traits indicate heterosis breeding as the best breeding method to improve the productivity of eggplant.
\end{abstract}

Keywords: diallel, eggplant, gene effect, heterosis, hybrid vigor

\section{Introduction}

Eggplant is an important vegetable crop of the tropical and subtropical regions of the world and has originated in India (Daunay et al., 2001). It belongs to the family Solanaceae and it is grown extensively in all parts of the world. Eggplant fruits have high nutritive value and high market demand (Chinedu et al., 2011). Therefore, its cultivation is most lucrative and remunerative (Kumar et al., 2012). The productivity of eggplant is low in Nigeria as compared to the other eggplant growing countries, owing to use of low yielding cultivars grown for local preference (Nalini, 2007). The present production, however, is not proportionate to the country's demand. Therefore, the crop deserves a deep deliberation for improvement. However, for the development of effective heterosis breeding programme in eggplant, one need to have the information about genetic architecture. Being that eggplant exhibits a huge genetic diversity for various traits which offers much scope for improvement through heterosis breeding the required goals of increasing productivity in the quickest possible time (Kumar et al., 2012).

Based on its rising demand especially of traits of consumers' preference, it is necessary to develop high yielding and high quality cultivars/hybrids of this crop. The gene actions among traits are the basis for initiating the effective breeding programme (Prasad et al., 2010). Plant breeders and geneticists often use diallel mating designs to obtain genetic information for an interest trait from a fixed or randomly chosen set of parental lines (Karami and Talebi, 2013; Prohens et al., 2017). The estimation of additive and nonadditive gene action through this technique could be useful in determining the possibility of commercial exploitation of heterosis and isolation of pure lines among the progenies of the good hybrids (Stuber, 1994). However, only few reports are available pertaining to the extent of hybrid vigour in eggplant yield. Hence, the present study was taken up with the following objectives (i) to generate information on genetic architecture of quantitative traits and (ii) to estimate the magnitude of heterosis in the hybrids of eggplant. 


\section{Materials and Methods}

The experiment was conducted at the Teaching and Research Field of Department of Crop Science, University of Nigeria, Nsukka, Nigeria. Nsukka (latitude $651^{1} \mathrm{E}$, and longitude $7^{\circ} 29^{1} \mathrm{~N}$ of $475 \mathrm{~m}$ above sea level), area characterized by lowland humid condition with bimodal annual rainfall distribution that ranges from $1,155 \mathrm{~mm}$ to $1,955 \mathrm{~mm}$, a mean annual temperature of $29^{\circ} \mathrm{C}$ to $31^{\circ} \mathrm{C}$ and relative humidity that ranges from $69 \%$ to $79 \%$ (Uguru et al., 2011).

The research was done from April, 2014 to July, 2015. Four superior and optimally divergent genotypes of eggplant namely 'Yalo', 'Uyo', 'K3' and 'Tyoyo' selected from the germplasm were crossed in half diallel mating design to generate six (6) single crosses during 2014 (April-July) planting season. Part of the seeds of parents and the $F_{1}$ were planted during August-December, 2014 to produce their $F_{2}$ and were cross to their respective parents to generate their backcross (BCP). The parents, $\mathrm{F}_{1}, \mathrm{~F}_{2}, \mathrm{BCP}_{1}$ and $\mathrm{BCP}_{2}$ of each cross were evaluated in a randomized complete block design (RCBD) with three replicates during April-July, 2015 .

Planting was done at a spacing of $70 \times 50 \mathrm{~cm}$ and inorganic compound fertilizer, N:P:K (20:10:10) was applied at the rate of $300 \mathrm{~kg}$ per hectare at two weeks after transplanting. Weeding was done manually on the field as when due.

Data were collected on the following parameters: plant height $(\mathrm{cm})$, number of leaves, number of branches, stem girth $(\mathrm{cm})$, days to $50 \%$ and $100 \%$ flowering, number fruits per plant, fruit yield per plant $(\mathrm{kg})$, fruit yield per hectare (tonnes) and fruit circumference $(\mathrm{cm})$ and diameter $(\mathrm{cm})$.

The performance of the $\mathrm{F}_{1}$ 's and their parents were used to determined heterosis according to Allard (1960) as follows: $100 / 1$

Heterosis over the mid parent $(\%)=\left(\mathrm{F}_{1}-\mathrm{BP}\right) / \mathrm{BP} \times$ $100 / 1$

Heterosis over better parent $(\%)=\left(\mathrm{F}_{1}-\mathrm{BP}\right) / \mathrm{BP} \times$

Where MP is mean of mid parent and is obtained by $\mathrm{P}_{1}+\mathrm{P}_{2} / 2, \mathrm{P}_{1}$ and $\mathrm{P}_{2}$ are both parents.

$\mathrm{BP}$ is mean of better parent; and $\mathrm{F}_{1}$ is mean of $\mathrm{F}_{1}$ 's.

Test of significance was also done as described by Kumar et al. (2011).

\section{$\mathrm{CD}=\sqrt{ }(2 m e / r) \times t$}

Where CD $=$ Critical Difference; $\mathrm{t}=\mathrm{t}$ tabulated at $5 \%$ probability; $\mathrm{r}=$ number replications; $m e=$ error mean square; $2=$ a constant.

The estimates of the various gene effects of the metric traits were obtained using generational mean data from the parental, $F_{1}$ 's, $F_{2}$ 's and backcrosses ( $\mathrm{BCP}_{1}$ 's and $\mathrm{BCP}_{2}$ 's) according to the relationship giving by Hayman (1958) model as explained by Singh and Chaudhary (1985) as follows:

$$
\begin{aligned}
& \mathrm{m}=\mathrm{F}_{2} \\
& a=\mathrm{B}_{1}-\mathrm{B}_{2} \\
& d=\mathrm{F}_{1}-4 \mathrm{~F}_{2}-\left(\frac{1}{2}\right) \mathrm{P}_{1}-\left(\frac{1}{2}\right) \mathrm{P}_{2}+2 \mathrm{~B}_{1}+2 \mathrm{~B}_{2} \\
& a a=2 \mathrm{~B} 1+2 \mathrm{~B} 2-4 \mathrm{~F} 2
\end{aligned}
$$

$$
\begin{aligned}
& a d=\mathrm{B}_{1}-\left(\frac{1}{2}\right) \mathrm{P}_{1}-\mathrm{B}_{2}+\left(\frac{1}{2}\right) \mathrm{P}_{2} \\
& d d=\mathrm{P}_{1}+\mathrm{P}_{2}+2 \mathrm{~F}_{1}+4 \mathrm{~F}_{2}-4 \mathrm{~B}_{1}-4 \mathrm{~B}_{2}
\end{aligned}
$$

Test of significant was done based on the relationship as describe by Gamble (1962).

$t$ value of effect $=($ gene effect $) / \sqrt{ }($ variance of gene effect)

Where $\mathrm{m}=$ mean of $\mathrm{F} 2, \mathrm{a}=$ additive gene effect, $\mathrm{d}=$ dominance gene effect, aa $=$ additive $\times$ additive gene effects, ad $=$ additive $\times$ dominance gene effects, $\mathrm{dd}=$ dominance $\times$ dominance gene effects, $B_{1}=$ Mean of backcross to Parent 1 , $\mathrm{B}_{2}=$ Mean of backcross to Parent $2, \mathrm{P}_{1}=$ Mean of Parent 1 , $\mathrm{P}_{2}=$ Mean of Parent 2, $\mathrm{F}_{1}=$ Mean of first filial generation, $\mathrm{F}_{2}=$ Mean of second filial generation.

\section{Results}

The results presented in Table 1 show the expression of heterosis of $F_{1}$ over mid parent $(\mathrm{MPH})$ on the agronomic traits of eggplant genotypes. The results revealed that the cross 'Yalo' $\times$ 'Uyo' had a positive significant $(\mathrm{p}<0.05)$ $\mathrm{MPH}$ in most of the traits such as number of fruits per plant $(66.40 \%)$, fruit yield per plant $(7.26 \%)$ and fruit yield per hectare (7.32\%). 'Yalo' $\times$ 'K3' showed a positive significant $\mathrm{MPH}$ in most of the traits, such as number of fruits per plant (158.90\%), fruit yield per plant $(31.11 \%)$ and fruit yield per hectare $(30.66 \%)$. The hybrid 'Yalo' $\times$ 'Iyoyo' showed a positive significant $\mathrm{MPH}$ in number of fruits per plant, fruit yield per plant and fruit yield per hectare of $102.28 \%, 21.57 \%$ and $18.01 \%$, respectively.

The cross 'Uyo' $\times$ 'K3' showed positive significant $\mathrm{MPH}$ in number of fruits per plant $(19.40 \%)$, fruit yield per plant $(21.05 \%)$ and fruit yield per hectare $(20.37 \%)$. The results obtained in a cross combination 'Uyo' $\times$ 'Iyoyo' showed positive significant MPH in number of fruits per plant (33.85\%), fruit yield per plant $(29.03 \%)$ and fruit yield per hectare (29.58\%). Hybrid 'K3' × 'Iyoyo' showed a positive significant MPH in number of fruits per plant, fruit yield per plant and fruit yield per hectare of $126.81 \%$, $63.14 \%$ and $62.20 \%$, respectively.

The expression of heterosis of $F_{1}$ over better parent $(\mathrm{BPH})$ presented in Table 2 revealed that the cross combination 'Yalo' $\times$ 'Uyo' had a positive BPH for number of fruits per plant (18.28\%). Non-significant positive $\mathrm{BPH}$ was obtained in fruit yield per hectare (7.68\%) from hybrid combination 'Yalo' $\times$ 'K3'). However, significant positive $\mathrm{BPH}$ of $104.08 \%$ was obtained in number of fruits per plant and fruit yield per plant (7.93\%).'Yalo' $\times$ 'Iyoyo' showed non-significant $\mathrm{BPH}$ in number of fruits per plant (16.06 $\%)$. 'Uyo' $\times$ 'K3' cross showed positive $\mathrm{BPH}$ in in number of fruits per plant $(3.36 \%)$ and fruit yield per hectare (7.89\%). Also significant positive $\mathrm{BPH}$ of $8.49 \%$ was obtained in fruit yield per plant. 'K3' $\times$ 'Iyoyo' showed significant positive $\mathrm{BPH}$ in number of fruits per plant (42.42\%), fruit yield per plant $(12.26 \%)$ and fruit yield per hectare $(11.51 \%)$.

The results presented in Table 3 shows various gene effects in the inheritance of agronomic traits in eggplant. The cross 'Yalo' $\times$ 'K3' showed that dominance $\times$ 
522

dominance effect had the highest positive magnitude of 45.70 in number of fruits per plant. The positive and highest dominance gene effect was found for number of fruits per plant (79.75) in cross 'Yalo' $\times$ 'Iyoyo' showed that to be in magnitude. For fruits yield per plant (1.76) and fruit yield per hectare (48.66) dominance $\times$ dominance gene effect had the highest positive values.

In the cross 'Uyo' $\times$ 'Iyoyo', the highest positive magnitude of dominance gene action was in number of fruits per plant (191.50), fruit yield per plant (0.86) and fruit yield per hectare (24.43). 'K3' × 'Iyoyo' cross showed that dominance gene action had the highest positive magnitude in number of fruits per plant (85.4), fruit yield per plant (2.42) and fruit yield per hectare (64.23).

\section{Discussion}

Heterosis shows the degree by which the means of the $F_{1}$ exceeds its better parent or the mid parent. The magnitude of heterosis depends on the accumulation of favourable dominant alleles in the $F_{1}$ (Amaefula et al., 2014). High positive mid and better parent heterosis observed in most of the agronomic traits of eggplant in the crosses suggests that all the crosses performed better than their parents in those traits. The negative MPH and $\mathrm{BPH}$ obtained in days to flowering was a desirable result indicating that the crosses are good materials for developing early maturing hybrids.

Cross combinations 'Yalo' $\times$ 'K3', 'Uyo' $\times$ 'K3' and 'K3' $\times$ 'Iyoyo' showed positive BPH in number of fruits per plant, fruit yield per plant and fruit yield per hectare. The result is in conformity with the findings of (Kumar et al., 2012; AL-Hubaity and Teli, 2013) who found positive mid parent, better parent and standard heterosis in the above mention traits in eggplant.

However, Amaefula et al. (2014) observed negative $\mathrm{BPH}$ in number of fruit per plant in tomato which is a contradictory report. Fruits circumference and diameter showed a negative $\mathrm{BPH}$ in the crosses. This could attribute to either wide diversity among the parents or the dominating gene effect of small fruit circumference and diameter over the large fruit circumference and diameter. Similar findings have also been reported by (AL-Hubaity and Teli, 2013).

Gene action is important in determining breeding methodology used to develop cultivar type (hybrid, pure line, synthetic, etc.). Dominance and dominance $x$ dominance gene effect showed high positive effect when compare to others gene effect in number of fruits per plant, fruits yield per plant and fruits yield per hectare in all the crosses indicating that these attributes are governed mainly by dominance gene action and could be exploited through heterosis breeding.

The result is in agreement with the findings of Chaudhary and Malhotra (2000), Panda et al. (2005), Prasad et al. (2010) who observed that number of fruits and fruit yield is governed by dominance gene effect in eggplant. However, the results contradict the findings of Mistry et al., (2016) who observed a significant additive gene effect in number of fruit per in some cross and early selection for improvement of this trait in eggplant.

Table 1. Estimates of heterosis (\%) in $\mathrm{F}_{1}$ over the mid parents (MP) for 11 agronomic traits of eggplant genotypes

\begin{tabular}{|c|c|c|c|c|c|c|c|c|c|c|c|}
\hline Crosses & $\overline{\mathrm{PH}}$ & NB & NL & SG & $\mathrm{D} 50 \mathrm{~F}$ & D100F & $\mathrm{FC}$ & FD & $\mathrm{NF}$ & $\mathrm{FY} / \mathrm{P}$ & $\mathrm{FY} / \mathrm{H}$ \\
\hline 'Yalo' × Uyo' & 16.49 & 33.58 & 13.41 & 4.59 & -6.59 & -6.58 & -5.07 & -2.92 & 66.40 & 7.26 & 7.32 \\
\hline 'Yalo’ × K3' & 5.94 & 14.75 & 16.00 & 22.79 & -15.21 & -11.58 & -7.80 & -11.85 & 158.90 & 31.11 & 30.66 \\
\hline 'Yalo' × Iyoyo' & 13.87 & 29.03 & 25.34 & 13.70 & 3.90 & -7.01 & -28.64 & -27.29 & 102.28 & 21.57 & 18.01 \\
\hline 'Uyo' × K3' & 8.96 & 26.17 & 26.63 & 13.83 & -2.79 & -4.90 & 6.42 & 6.03 & 19.40 & 21.05 & 20.37 \\
\hline 'Uyo' × Iyoyo' & 6.81 & 2.14 & 7.98 & 0.28 & -11.49 & -8.49 & -8.26 & -5.59 & 33.85 & 29.03 & 29.58 \\
\hline 'K3' × Iyoyo' & 15.38 & 23.58 & 24.30 & 6.20 & 18.29 & 0.00 & -11.72 & -14.79 & 126.81 & 63.14 & 62.20 \\
\hline SE & 3.35 & 4.00 & 24.80 & 0.21 & 1.63 & 1.43 & 0.65 & 0.46 & 10.93 & 0.18 & 5.06 \\
\hline $\mathrm{CD}(\mathrm{p}<0.05)$ & 10.06 & 6.94 & 43.25 & 0.35 & 2.83 & 2.48 & 1.14 & 0.79 & 18.95 & 0.3 & 8.78 \\
\hline
\end{tabular}

$\mathrm{D} 50 \mathrm{~F}=$ Days to $50 \%$ flowering, D100F = Days to $100 \%$ flowering, $\mathrm{FC}=$ Fruit circumference $(\mathrm{cm}), \mathrm{FD}=$ Fruit diameter $(\mathrm{cm}), \mathrm{NB}=\mathrm{Number}$ of branches per plant, $\mathrm{NF}=$ Number of fruits per plant, $\mathrm{NL}=$ Number leaves per plant, $\mathrm{PH}=\mathrm{Plant}$ height $(\mathrm{cm}), \mathrm{SG}=\mathrm{Stem}$ girth $(\mathrm{cm}), \mathrm{FY} / \mathrm{P}=\mathrm{Fruits}$ per plant $(\mathrm{kg}), \mathrm{FY} / \mathrm{H}=\mathrm{Fruits}$ yield per hectare (tone/ha), $\mathrm{SE}=\mathrm{Standard}$ error, $\mathrm{CD}=\mathrm{Critical}$ differences

Table 2. Estimates of heterosis (\%) in $\mathrm{F}_{1}$ over the better parents (BP) for 11 agronomic traits of eggplant genotypes

\begin{tabular}{|c|c|c|c|c|c|c|c|c|c|c|c|}
\hline Crosses & $\mathrm{PH}$ & $\mathrm{NB}$ & NL & SG & $\mathrm{D} 50 \mathrm{~F}$ & $\mathrm{D} 100 \mathrm{~F}$ & $\mathrm{FC}$ & FD & $\mathrm{NF}$ & $\mathrm{FY} / \mathrm{P}$ & $\mathrm{FY} / \mathrm{H}$ \\
\hline 'Yalo' ×’Uyo' & 13.99 & 23.66 & 13.35 & 1.88 & -8.96 & -7.98 & -22.16 & -24.09 & 18.28 & -18.9 & -18.76 \\
\hline 'Yalo' × 'K3' & 2.06 & 3.67 & 5.73 & 15.54 & -20.5 & -13.74 & -19.92 & -22.65 & 104.08 & 7.93 & 7.68 \\
\hline 'Yalo' × 'Iyoyo' & 13.60 & -48.16 & -7.44 & -2.99 & -15.38 & -11.32 & -53.89 & -54.95 & 16.06 & -24.39 & -26.57 \\
\hline 'Uyo' × 'K3' & 7.25 & 21.58 & 15.36 & 9.85 & -5.43 & -5.88 & -4.68 & -7.29 & 3.36 & 8.49 & 7.89 \\
\hline 'Uyo’ × 'Iуоуо' & 4.76 & -31.51 & -20.23 & -16.24 & -21.65 & -13.98 & -31.15 & -31.63 & -9.66 & -4.76 & -4.56 \\
\hline 'K3' × 'Iyoyo' & 11.41 & -18.35 & -13.45 & -13.79 & 10.03 & -6.85 & -38.35 & -43.16 & 42.43 & 12.26 & 11.51 \\
\hline SE & 3.35 & 4.00 & 24.80 & 0.21 & 1.63 & 1.43 & 0.65 & 0.46 & 10.93 & 0.18 & 5.06 \\
\hline $\mathrm{CD}(\mathrm{p}<0.05)$ & 10.06 & 6.94 & 43.25 & 0.35 & 2.83 & 2.48 & 1.14 & 0.79 & 18.95 & 0.30 & 8.78 \\
\hline
\end{tabular}

$\mathrm{D} 50 \mathrm{~F}=$ Days to $50 \%$ flowering, D100F = Days to $100 \%$ flowering, $\mathrm{FC}=$ Fruit circumference $(\mathrm{cm}), \mathrm{FD}=$ Fruit diameter $(\mathrm{cm}), \mathrm{NB}=\mathrm{Number}$ of branches per plant, $\mathrm{NF}=$ Number of fruits per plant, $\mathrm{NL}=$ Number leaves per plant, $\mathrm{PH}=$ Plant height $(\mathrm{cm}), \mathrm{SG}=\mathrm{Stem}$ girth $(\mathrm{cm}), \mathrm{FY} / \mathrm{P}=$ Fruits per plant $(\mathrm{kg}), \mathrm{FY} / \mathrm{H}=\mathrm{Fruits}$ yield per hectare (tone/ha), ), SE= Standard error, $\mathrm{CD}=$ Critical differences 
Table 3. Estimates of gene effects for 11 agronomic traits in eggplant

\begin{tabular}{|c|c|c|c|c|c|c|c|}
\hline Crosses & Traits & $m$ & $a$ & $d$ & $a a$ & $a d$ & $d d$ \\
\hline \multirow[t]{11}{*}{ 'Yalo' x'K3' } & $\mathrm{PH}$ & 70.66 & 5.00 & 18.81 & 14.48 & 7.78 & -10.53 \\
\hline & NB & 19.99 & -1.00 & -6.17 & -8.64 & -2.97 & 9.26 \\
\hline & NL & 89.00 & 1.20 & 42.55 & 28.8 & -7.15 & -42.30 \\
\hline & SG & 5.11 & 0.62 & -2.26 & $-3.24^{*}$ & 0.32 & $5.19^{*}$ \\
\hline & $\mathrm{D} 100 \mathrm{~F}$ & 29.33 & 3.33 & -2.82 & 0.02 & 4.16 & 7.69 \\
\hline & D50F & 20.67 & $3.67^{*}$ & 4.33 & 8.66 & 3.34 & -9.36 \\
\hline & $\mathrm{FC}$ & 19.89 & $3.90^{*}$ & 1.12 & 2.12 & 0.74 & -1.50 \\
\hline & FD & 9.54 & 1.31 & 0.77 & 1.00 & -0.15 & 0.89 \\
\hline & NF & 23.00 & $-13.50^{* *}$ & 11.15 & -13.40 & $-9.35^{* *}$ & $45.70^{* *}$ \\
\hline & $\mathrm{FY} / \mathrm{P}$ & 1.18 & 0.11 & 1.98 & 2.40 & -0.18 & -2.44 \\
\hline & $\mathrm{FY} / \mathrm{H}$ & 33.62 & 2.95 & $68.80^{* *}$ & $56.62^{* *}$ & -5.29 & $-70.16^{* *}$ \\
\hline \multirow{11}{*}{ 'Yalo’ × 'Iyoyo' } & $\mathrm{PH}$ & 72.00 & -0.62 & $38.15^{* *}$ & 27.88 & -0.45 & -41.20 \\
\hline & $\mathrm{NB}$ & 40.00 & -9.60 & 8.69 & -0.80 & 4.39 & -4.51 \\
\hline & $\mathrm{NL}$ & 163.40 & -31.60 & -100.60 & -137.60 & 20.1 & $279.60^{*}$ \\
\hline & SG & 3.98 & 0.20 & -0.93 & -1.40 & -0.39 & 1.54 \\
\hline & D50F & 26.00 & 2.00 & -5.82 & -5.32 & -1.5 & -4.36 \\
\hline & D100F & 36.00 & 1.67 & -14.82 & -12.66 & 0.17 & 0.32 \\
\hline & $\mathrm{FC}$ & 11.80 & $8.20^{* *}$ & 1.71 & 5.36 & -0.31 & -3.06 \\
\hline & $\mathrm{FD}$ & 5.53 & $3.00^{* *}$ & -0.30 & 1.58 & $-1.43^{* *}$ & $6.38^{* *}$ \\
\hline & NF & 48.00 & $-41.20^{* *}$ & 79.75 & 34.30 & -8.55 & 4.10 \\
\hline & $\mathrm{FY} / \mathrm{P}$ & 0.89 & $0.40^{*}$ & -0.18 & -0.40 & -0.22 & 1.76 \\
\hline & $\mathrm{FY} / \mathrm{H}$ & 25.43 & $11.53^{*}$ & -6.33 & -11.62 & -5.99 & $48.66^{*}$ \\
\hline \multirow[t]{11}{*}{ 'Uyo' × 'Iyoyo' } & $\mathrm{PH}$ & 85.11 & -1.11 & -6.63 & -11.54 & -2.52 & -18.95 \\
\hline & NB & 29.00 & $-16.23^{* *}$ & 27.09 & 26.42 & -0.84 & -14.78 \\
\hline & NL & 126.10 & $-57.20^{* *}$ & $180.85^{*}$ & $169.20^{*}$ & -5.55 & -235.3 \\
\hline & SG & 4.31 & 0.15 & -1.09 & -1.10 & -0.56 & -0.83 \\
\hline & $\mathrm{D} 50 \mathrm{~F}$ & 25.00 & -2.33 & -5.85 & -3.34 & -5.17 & -10.99 \\
\hline & D100F & 36.67 & -2.67 & -16.67 & -17.34 & -4.67 & 14.66 \\
\hline & $\mathrm{FC}$ & 9.00 & $3.52^{* *}$ & 4.33 & 5.20 & 0.02 & -6.02 \\
\hline & FD & 4.17 & $1.86^{*}$ & 2.52 & 2.78 & 0.02 & 1.71 \\
\hline & NF & 44.90 & $-60.60^{* *}$ & $191.50^{* *}$ & $174.00^{* *}$ & $-35.70^{*}$ & $-285.80^{* *}$ \\
\hline & $\mathrm{FY} / \mathrm{P}$ & 0.74 & 0.18 & 0.86 & 0.68 & -0.04 & -1.48 \\
\hline & $\mathrm{FY} / \mathrm{H}$ & 21.24 & 5.24 & 24.43 & 19.24 & -1.10 & -42.02 \\
\hline \multirow[t]{11}{*}{ 'K3' × 'Iyoyo' } & $\mathrm{PH}$ & 82.89 & 12.89 & -8.76 & -20.02 & 10.28 & 24.14 \\
\hline & $\mathrm{NB}$ & 41.22 & $-24.56^{*}$ & 9.93 & 2.68 & -8.59 & -32.74 \\
\hline & $\mathrm{NL}$ & 191.80 & -4.10 & -72.35 & -105.80 & $55.95^{*}$ & 61.90 \\
\hline & SG & 4.10 & 0.83 & -1.07 & -1.3 .00 & -0.04 & 1.47 \\
\hline & $\mathrm{D} 50 \mathrm{~F}$ & 26.00 & -2.34 & -9.5 & -14.00 & -4.51 & 17.66 \\
\hline & D100F & 37.33 & 1.67 & -24.66 & -24.66 & -0.67 & 26.67 \\
\hline & $\mathrm{FC}$ & 9.86 & $5.35^{* *}$ & 1.89 & 3.34 & 0.00 & 0.42 \\
\hline & $\mathrm{FD}$ & 4.72 & $2.40^{* *}$ & 0.30 & 1.18 & -0.57 & 0.81 \\
\hline & NF & 90.30 & $-53.20^{*}$ & 85.40 & 24.4 & -24.70 & -95.60 \\
\hline & $\mathrm{FY} / \mathrm{P}$ & 0.76 & 0.56 & 2.42 & 1.16 & 0.23 & -0.15 \\
\hline & $\mathrm{FY} / \mathrm{H}$ & 21.62 & 7.14 & $64.23^{*}$ & $51.24^{*}$ & -2.33 & $-79.35^{*}$ \\
\hline
\end{tabular}

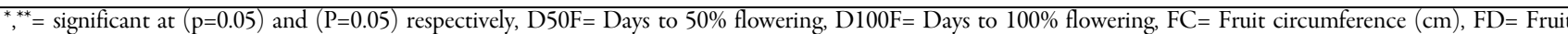
diameter $(\mathrm{cm}), \mathrm{NB}=$ Number of branches per plant, $\mathrm{NF}=$ Number of fruits per plant, $\mathrm{NL}=\mathrm{Number}$ leaves per plant, $\mathrm{PH}=\mathrm{Plant}$ height $(\mathrm{cm}), \mathrm{SG}=\mathrm{Stem}$ girth $(\mathrm{cm})$, $\mathrm{FY} / \mathrm{P}=$ Fruits per plant $(\mathrm{kg}), \mathrm{FY} / \mathrm{H}=$ Fruits yield per hectare (tonnes/ha), $\mathrm{m}=\mathrm{F}_{2}$ mean, $\mathrm{a}=$ additive gene effect, $\mathrm{d}=$ dominance gene effect, aa= additive $\mathrm{x}$ additive gene effect, $\mathrm{ad}=$ additive $\mathrm{x}$ dominance gene effect, $\mathrm{dd}=$ dominance $\mathrm{x}$ dominance gene effect 
524

High positive additive gene effect was obtained in fruit circumference and diameter in all crosses indicating that these attributes can be fixed for possible selection of promising genotypes at the early generation. This result is in accordance with Prasad et al. (2010) who observed that additive gene had the highest positive value when compare with other gene effect in length and breadth of fruits in eggplant but this result is not in support of the findings of Mistry et al. (2016) that found positive and significant dominance gene effect for fruit length and fruit girth in eggplant. High magnitude of dominance and dominance $x$ dominance gene effect in yield traits indicate heterosis breeding as the best breeding method to improve the productivity of this crop.

\section{Conclusions}

A better parent heterosis (BPH) which can be important to eggplant breeders, was obtained in 'Yalo' $x$ 'K3' and 'Uyo' $\times$ 'K3' genotypes for fruit yield. Dominance and dominance $x$ dominance gene effect was found to be positive and higher in magnitude in all crosses for number of fruits per plant, fruit yield per plant and fruit yield per hectare indicating hybrid breeding is the best breeding method to improve the productivity of this crop. Additive and additive $\times$ additive gene effect was positive and high in magnitude for some growth trait studied. The results indicated that for the improvement of these growth traits such as plant height, number branches and number of leaves, selection breeding method is a more appropriate method to adopt in eggplant genotypes.

\section{References}

Al-Hubaity AI, Teli JA (2013). Combining ability and heterosis in eggplant (Solanum melongena L.) Mesopotamia Journal of Agriculture 41(1):2335.

Allard RW (1960). Principles of plant breeding. John Willey and Sons Inc., New York.

Amaefula C, Agbo CU, Nwofia GE (2014). Hybrid vigour and genetic control of some quantitative traits of tomato (Solanum lycopersicum $\mathrm{L}$.). Open Journal of Genetics 4(1):30-39.

Chaudhary DR, Malhotra SK (2000). Combining ability of physiological growth parameters in brinjal (Solanum melongena L.). Indian Journal of Agricultural Research 34(1):55-58.

Chinedu SN, Olasumbo AC, Eboji OK, Emiloju OC, Arinola OK, Dania DI (2011). Proximate and phytochemical analysis of Solanum etiopicum L. and Solanum macrocarpon L. fruits. Research Journal of Chemical Sciences 1(3):63-71.
Daunay MC, Lester RN, Gebhardt CH, Hennart JW, Jahn M, Frary A, Doganlar S (2001). Genetic resources of eggplant (Solanum melongena L). and allied species: A new challenge for molecular geneticists and eggplant breeders. Nijmegen University Press, Nijmegen, Netherlands, pp251-274.

Gamble EE (1962). Gene effects in corn (Zea mays L.) relative importance of gene effects for plant height and certain components attributes of yield. Canadian Journal of Plant Science 42:349-358.

Hayman B (1958). The separation of epistatic from additive and dominance variation in generation means. Heredity 12:371-390.

Karami E, Talebi R (2013). Nature of gene action and genetic parameters for yield and its components in chickpea. African Journal of Biotechnology 12:7038-7042.

Kumar A, Mishra VK, Vyas RP, Singh V (2011). Heterosis and combining ability analysis in Bread Wheat (Triticum aestivum). Journal of Plant Breeding and CropScience 3:209-217.

Kumar SR, Arumugam T, Anandakumar, Rajavel DS (2012). Estimate of heterosis and specific combining ability for yield, quality, pest and disease incidence in eggplant (Solanum melongena L.) Bulletin of Environment, Pharmacology and Life Sciences 2(1):3-15.

Mistry C, Keshubhai KB, Sabolu S, Kumar S (2016). Heritability and gene effect for yield related quantitative traits in eggplant. Annals of Agricultural Sciences 61(2):237-246.

Nalini D (2007). Studies on heterosis and combining ability in eggplant (Solanum melongena L.). MSc. (Hort) Thesis, University of Agricultural Sciences, Dharwad.

Panda B, Singh YV, Ram HH (2005).Studies on heritability, genetic advance and genetic component of variation in round-fruited eggplant (Solanum melongena L.). Horticultural Journal 18:46-50.

Prasad V, Dwivedi VK, Deshpande AA, Singh BK (2010). Gene action of economic traits in brinjal (Solanum melongena L.) Vegetable Science 37(1):97-99.

Prohens J, Gramazio P, Plazas M, DempewolfH, Kilian B, Díez MJ, Fita A, Herraiz FJ, Rodríguez-Burruezo A, Soler S, Knapp S (2017). Introgressiomics: a new approach for using crop wild relatives in breeding for adaptation to climate change. Euphytica 213(7):158.

Singh RK, Chaudhary BD (1985). Biometrical methods in quantitative genetic analysis. Kalyani Publishers. New Delhi-Ludhiana (India) pp 3978.

Stuber CW (1994). Heterosis in plant breeding. Plant Breed Review 12:227-251.

Uguru MI, Baiyeri KP, Abba SC (2011). Indicators of climate change in the derived Savannah Niche on Nsukka, South-Eastern Nigeria. AgroScience 10(1):1-10. 